\title{
Dividends Announcement and Semi Strong Form of Efficiency at The Nairobi Securities Exchange in Kenya
}

\author{
Duncan Turere ${ }^{1}$, Dr. Tobias Olweny, Ph.D ${ }^{2}$ \\ ${ }^{1}$ Post Graduate Student, School of Business, Jomo Kenyatta University of Agriculture and Technology, Kenya \\ ${ }^{2}$ Lecturer School of Business, Jomo Kenyatta University of Agriculture and Technology, Kenya \\ Corresponding Author's: Duncan Turere
}

\begin{abstract}
The objective of this study was to establish the effects of dividend announcement to current market prices at the Nairobi Securities Exchange, with four specific objectives; to determine the information content of dividend announcements, to determine the extent to which prices converge to new values after dividend announcements on a sector by sector basis, to establish the market reaction to announced information and also to establish whether investors can secure excess returns by acting on announced information. A 66 days event timeline was employed from 2005 to 2015 on daily closing stock prices. A sample of 179 dividend announcements from 22 listed companies in 8 sectors were drawn and analysed using an OLS Market Model. Findings of the research conclude that; dividend announcements do have an impact on stock prices for the Agricultural, Banking, Commercial, Construction, Manufacturing and Telecomm Sectors and not for the Energy Sector, Insurance Sector and the Nairobi Securities Exchange Market. It takes more than five days for prices to adjust to their correct values and this makes it possible for market players to profit from the inefficiency by earning abnormal returns. We conclude that the Nairobi Securities Exchange is not semistrong form efficient.
\end{abstract}

\section{KEYWORDS: Event Study, Dividend Announcement, NSE, CMA, Semi-strong form efficiency, Abnormal Returns}

\section{INTRODUCTION}

The Nairobi Securities Exchange was formally started in 1954. The Government saw the exchange as a medium of raising finances while the brokers viewed it as source of raising funds for the expansion of the private enterprise (Muragu, 1990). In the recent years we have evidenced changes at the Nairobi Securities Exchange (NSE) The most notable are; settlement period moved from $\mathrm{T}+4$ (Transaction date-T plus 4 Days) to $\mathrm{T}+3$, live automated trading system (ATS) of securities, Dual listing within East African Security Exchange Associations, Review of the 20 Share Index in 2007, Introduction of the NSE All Share Index (NASI), demutualization of the NSE; the exchange became the second in Africa to demutualize after the Johannesburg Stock Exchange. (Nairobi Securities Exchange (NSE), 2015).

The legal framework governing the operations of NSE has had its share of changes; in 1989 the Capital Markets Authority (CMA) was established to promote and maintain an effective and efficient market (Muragu, 1990). The CMA remains the regulatory authority charged with the responsibility of supervising, licensing and monitoring the activities of market intermediaries. A number of legislations have been passed to regulate the market which include; regulation of futures exchange, real estate investments, public offers, listing and disclosure, demutualization of the NSE, licensing requirements, foreign investors regulation, take over and mergers, collective investment schemes, Operational Rules, asset backed securities, venture capitalist among others. (CMA, 2014)

The above changes are geared towards efficiency of the market, it is therefore imperative to establish whether NSE is efficient. The availability of information on the market is pertinent as it helps to determine the level of efficiency and sophistication attained by the market (Olweny, 2012).The efficient market hypothesis stipulates that whatever information you consider in making a decision has already been incorporated into prices and is useless for predicting future prices (Fama E. F., 1970). Fama goes ahead and classifies market efficiency into three categories. Weak Form Efficiency - asserts that current price fully incorporates all historical information of past prices movement only. The semi-strong form of market efficiency hypothesis suggests that the current price fully incorporates all publicly available information. Neither technical nor fundamental analysis can find a way for gaining excess returns. This form of market efficiency was researched. The strong form of market efficiency hypothesis states that the current price fully incorporates all existing information, both public and private (sometimes called insider information). 
Despite the above initiatives and achievements the Market still faces several challenges, namely; inconsistent use of the capital markets by domestic and regional entities for capital mobilization; weaknesses in the conduct of business by intermediaries which have contributed to retail investor apathy and constraints on international investment flows thereby affecting liquidity in the market (Capital Markets Master Plan Steering Committee (CMMSC), 2014). A narrow retail investor base; $4 \%$ of the population currently participates in the local market (Oxford Business Group, 2016). Studies have documented contradictory evidence; (Muthama, 2013) indicates that the NSE appears to be an inefficient market, suggesting that there are opportunities to make excess returns which investors and market analysts can exploit. (Muragu, 1990)- indicates that small markets, such as the NSE, may provide empirical results consistent with weak-form efficiency. The NSE is not semi-strong form efficient as some investors can earn abnormal returns by having unequal access to public information (Olweny, 2012). Olweny, recommends further research on effects of dividend announcements on firm value to be conducted on a sector by sector basis, this was addressed in this research. This will help uncover the effect of dividend announcement on firm value on a sector by sector basis and what this implies on the efficiency of the NSE (Olweny, 2012).

\section{MAIN OBJECTIVE}

The aim of the study was to establish the effects of dividend announcements to current market prices at the Nairobi Securities Exchange.

\section{A. Specific objectives}

i) To determine the information content of dividend announcements to market prices

ii) To determine the extent to which prices converge to new values after dividend announcements on a sector by sector basis

iii) To establish the market reaction to dividends announcement

iv) To establish whether investors can secure excess returns by acting on announced information

\section{THEORETICAL REVIEW}

\section{A. Random Walk theory}

The random walk theory asserts that price movements will not follow any patterns or trends and that past price movements cannot be used to predict future price movements. In an efficient market at any point in time the actual price of a security is a good estimate of its intrinsic value. (Fama E. F., 1965-1974). Fama, states that, in uncertain world the intrinsic value can never be ascertained exactly. Thus there is always room for disagreement among market participants concerning what they deem is an intrinsic value of a security. In an efficient market such discrepancies between actual prices and intrinsic values should cause the actual price of the security to wander randomly about its intrinsic value.
If the discrepancies between actual prices and intrinsic values are systematic rather than random in nature, then the knowledge of this should help market participants to better predict the prices towards intrinsic values. When many traders try to take advantage of this they will tend to neutralize such systematic behavior in price series. (Fama E. F., 19651974). In an efficient market on average competition will cause the full effect of new information on intrinsic value to reflect "instantaneously" in actual price. Instantaneous adjustment has two implications; first, it might lead to overadjustment or under-adjustment to the intrinsic value. Second, the lag in the complete adjustment of actual prices to successive new intrinsic values will itself be an independent random variable. This means that instantaneous adjustment property of an efficient market implies that successive price changes in individual securities will be independent. (Fama E. F., 1965-1974)

A market where successive price changes in individual securities are independent is by definition, a random walk market. The theory of random walk implies that a series of stock price changes has no memory-the past history of the series cannot be used to predict the future. (Fama E. F., 19651974), Serial correlation coefficients and analysis of runs of consecutive price changes of the same sign can be used to test the rand walk model. If the statistical tests tend to support the assumption of independence, then one can conclude that the historical prices cannot be used to predict market prices. (Fama E. F., 1965-1974). If the random walk theory is valid and security exchanges are efficient markets, then stock prices at any point will represent estimates of intrinsic or fundamental analysis, additional fundamental analysis will be of value if there is additional information which is not fully considered in forming current market prices.

\section{B. Efficient market hypothesis}

Efficient market hypothesis holds that any new information about a firm is incorporated into share prices rapidly and rationally with respect to the direction and magnitude of the share price movement. Fama presented the complete efficient market hypothesis in his paper: "Efficient capital markets: A review of theory and empirical work" in 1970. He defined the efficient market as the one where "... security prices at any time "fully reflect" all available information (Fama E. F., 1970). He further distinguished three forms of market efficiency: weak, semi-strong and strong.

Weak form of market efficiency implies that the future stock price developments are completely random, and no technical analysis can consistently help bit the market. To prove this form of efficiency to be present one should find no serial dependence among stock prices, no stock price movement patterns can be consistent over time.

Semi-strong form implies that investors cannot earn abnormal returns by trading on the new publicly available information as the information is immediately incorporated into stock prices. Neither technical nor fundamental analysis can find a way for beating the market. The speed of stock price 
adjustment is the determinant of this form of efficiency which can be tested with the highest certainty using the event study's methodology (Fama E. F., 1991). If no miss-reaction or delayed reaction of investors is discovered after the news announcement, the market is semi-strong efficient. This form of market efficiency was researched.

Strong form of the market efficiency claims that at any point in time the share prices have fully incorporated all available information (both public and private information) and nobody can gain excess returns. Usually to test this form of efficiency it is looked whether someone can consistently earn higher than market index returns for a long period of time and currently there is no clear answer to this issue. (Jansen, 1968) Claims that "on average the funds apparently were not quite successful enough in their trading activities to recoup even their brokerage expenses", which proves the prevalence of the strong form of EMH. However, in 1991 Fama (Fama E. , 1991) reviews mutual funds performance and finds that some mutual funds actually out-performed the market by gaining tiny excess returns. Nevertheless, it does not prove anything as when there are thousands of investors, according to the normal distribution it is probable that some will actually beat the market. From the event study point of view, strong form of efficiency can be rejected if there are pre-event abnormal returns that signal trading based on insider information.

\section{Dividend Signalling Theory}

Market players are likely to interpret a change in dividend as a change in management's views of future profit prospects for the firm thus triggering share returns. Ross states that if managers possess insider information, then the choice of a managerial incentive and of the financial structure signals information to the market (Ross, 1977). In a competitive market the inferences drawn from the signals will be validated (Ross, 1977). Investors observe the firm's sources of funds and its utilization of funds including the overall dividend and then collectively price the firm (John \& Williams, 1985). In a perfectly competitive market, both managers who are insiders and investors who are outsiders regard the pricing function as fixed by market forces. At equilibrium, managers of firms with valuable future cash inflows distribute larger dividends and receive higher prices for their stock whenever the demand for cash by both their firm and its current stockholders exceeds its internal supply of cash (John \& Williams, 1985). Fuller and Thakor postulate that firms can be classified into three groups based on their history of performance; firms with the poorest prior performance pay the lowest dividends because they are correctly identified and therefore nothing to signal and they do face a Low Free-Cash-Flow (FCF) problem. Firms with the best performance are correctly identified in the market, they have no signalling concerns and pay higher dividends to cope with the High Free-Cash-Flow (FCF) problem. However, firms with intermediate prior performance pay dividend to resolve Free-Cash-Flow (FCF) problem and also to signal the market in order to separate them from prior poor performance (Fuller \& Thakor, 2010). Fuller and Thakor conclude that because of the confusion instigated by what the market knows and what it does not know at the time of the signalling situation, FCF and signalling argument can be used in many other aspects and not only in capital structure signalling. Balachandran, Dempsey, \& Mahamuni state that managers pay special dividends to signal future performance of firms with high growth opportunities. The market reacts moderately to the special dividend announcement of a firm with higher growth opportunities and higher preannouncement cash flow, whereas the reaction is insignificant for firms with higher growth opportunities and lower preannouncement free cash flow (Balachandran, Dempsey, \& Mahamuni, 2009). Dividends have a signalling role regarding agency costs in that dividends are able to diminish insider conflict or may be used to reduce free cashflows which could be predominant in emerging markets (Chen \& Oriani, 2015). Chen et al state that participation of foreign investors in emerging markets has been neglected and ownership of structures and institutional backgrounds are different from those of developed economies. Where cross listing is in place, a firm is subjected to different transparency, governance and disclosure requirements depending on the jurisdiction (Chen $\&$ Oriani, 2015). In their paper Chen \& Oriani conclude that empiracal results in China indicate that dividends play a signalling role as investors incorporate this information when making investment decisions hence affecting share prices. The major agency problem experienced is however between autonomous managers and shareholders thus dividends are used as signals to indicate reduced/increased agency problem (Chen \& Oriani, 2015).

\section{EMPIRICAL REVIEW}

\section{A. Dividend Announcements}

The initial task of conducting an event study is to define the event of interest (Campbell, Lo, \& MacKinlay, 1997). Dividends announcement signal the market players on the performance of a company listed in the market. Dharmarathne (2013) examines stock price reaction to subsequent dividend announcements and information efficiency in Sri Lankan Share Market with a sample of 61 major companies from those listed on the Colombo Stock Exchange (CSE), which had made 137 dividends announcements for the period 1998 to 2008. The Market Model Methodology was applied in generating the Abnormal Returns surrounding the event day. The significance of the CAAR for the event period was tested using the t-statistic. The author states that despite the pre and post announcements effect the market reaction did not yield considerable figures and therefore concludes that the market is semi strong form efficient subsequent to the dividend announcements, dividends contain considerable information and the market reacted in an efficient manner to new dividend information. Research conducted at the NSE indicated that Dividend policy influence the share prices and therefore companies 
listed at NSE should pay dividends to maintain high share prices (Waithaka, Ngugi, Aiyabei, Itunga, \& Kirago, 2012). Dividend policy helps the management of a company decide on how much dividend to pay to shareholders and how much earnings are ploughed back to the company (Waithaka, Ngugi, Aiyabei, Itunga, \& Kirago, 2012). The study concluded that an increase in firm's stocks trading volume affected the share price and those investors who wanted current investment income owned shares in high dividend payout firms.

\section{B. Price Convergence}

Semi-strong form implies that investors cannot earn abnormal returns by trading on the new publicly available information (earnings, dividend and capital structure, management change announcements, etc.) as the information is immediately incorporated into stock prices. Neither technical nor fundamental analysis can find a way for beating the market. The speed of stock price adjustment is the determinant of this form of efficiency which can be tested with the highest certainty using the event study's methodology (Fama E. F., 1991). Anwar et'al in their paper published in 2015 used the event study methodology, they examined the effect of cash dividends announcements to stock prices volatility that reflect investor's expectations of risk and return. The secondary data was collected from prowess database maintained by the Centre of Monitoring Indian Economy and the Bombay Stock Exchange. To fill the gap of the impact of cash dividend announcements; the paper measured the magnitude and direction of change in risk (both short-term and long-term) upon the announcements of cash dividends (Anwar, Singh, \& Jain, 2015). The authors tested two null hypotheses; $H_{0}$ : There is no significant difference in short-term risk before and after the announcement date of dividends. $H_{0}$ : There is no significant difference in long-term risk before the announcement date and after the ex-date of cash dividends. The authors conclude that; in short run, an increase in variance was reported which was roughly two times greater than the non-information period. The probable reason for an increase in event-period returns volatility in short-run may be due to 'low information environment'. In long run, the stocks seem to be less volatile due to the less intensity at which information arrives and is incorporated into security prices when stock exchanges are open. There seems to be a shift in investors' focus in long-run on information content of dividend announcements leading to a marginal decrease in 60 -day variance as compared to 120 -day period. These results justify the signaling ability of cash dividends announcements (Anwar, Singh, \& Jain, 2015). The implications of the study were that managers may employ dividend policies to influence stock prices. For short term investment, investors can earn capital gains by investing in stocks that prices are highly volatile, and this is during the dividend announcements window. Kabiru, Ochieng, \& Kinyua (2015) provided evidence on the effect of general elections on stock returns at NSE. The performance of the financial markets is significantly impacted by the political environment during general elections, empirical results have given inconsistent results on whether general election negatively or positively impact NSE (Kabiru, Ochieng, \& Kinyua, 2015). The authors inform investors that they should be cautious during elections and on the other hand, policy makers should implement policies that caution the market against political risk during elections to bolster investor confidence (Kabiru, Ochieng, \& Kinyua, 2015). They recommend further studies could be done to analyze the performance of stock returns in nonelectioneering periods to compare their performance prior to election periods.

\section{Market Reaction}

(Johannes, 2015) tested the Namibian stock market for strong form efficiency for the period covering 1997 to 2012. Monthly data was used for the period of study and the secondary data was obtained from the Bank of Namibia and Namibia Stock Exchange. The study hypothesized that the Namibian stock market is not semi-strong form efficient. Johannes employed econometric techniques to carry out the tests, Autoregressive Heteroscedacity (ARCH) and Generalized Autoregressive Conditional Heteroscedacity (GARCH) were used. The use of the GARCH model was supported due to the ability of the model to allow a timevariant conditional variance and non-linearity. In addition, it captures both volatility clustering and unconditional return distribution with heavy tails. To test the market any case of prices overshooting should be captured through the volatility of the market. Presence of volatility is determined by summing up the root of the autoregressive model of $\alpha+\beta$. From the results of the study the summation of the two coefficients from the ARCH and GARCH models was greater than 0.5 which supported the weak form efficiency and does not support the hypothesis of strong form efficiency. The results of the study therefore conclude that investors cannot bit the market using historical data but there is a possibility of market players beating the market if they are in possession of private information (Johannes, 2015). The study recommends that Namibia should develop its capital market and reduce capital outflows and address the issue of thin trading. Johannes further recommends that future studies could employee that market testing methodologies and compare the results.

(Waweru \& Otieno, 2016) examined the Nairobi Securities Exchange (NSE) in order to provide empirical evidence on whether change in cash dividends announcements affects stock prices. The authors examined if stock returns react the same to an increase and a decrease in cash dividend declared by a listed company. Closing security prices of 2012 to 2015 were used, a sample of 44 companies were picked for listed companies that paid cash dividends in the year, daily closing data was obtained from NSE website and dividends paid was collected from the company's records, 325 observations were used. A 40day event methodology was used to determine the reaction of prices before and after the event day; returns for 
20 days before the event and 20 days after the event were analysed. The market return model was used to measure abnormal returns during the event period. A two-sample t-test tested if AAR and CAR influenced share price movements. The results revealed there was statistically significant $(\mathrm{P}<0.05)$ difference between the means before cash dividend announcements and after cash dividend announcements in both AAR and CAR. The paper also examined the effect of cash dividend increase and decrease announcements on share price returns-results revealed there was statistically significant $(\mathrm{P}<0.05)$ difference between the means before cash dividend increase and after cash dividend increase (Waweru \& Otieno, 2016). Waweru and Otieno concluded that dividends have an effect on share prices at NSE, a decrease in cash dividends resulted in a decrease in returns and an increase in cash dividends resulted in increase in stock prices (Waweru \& Otieno, 2016). The authors go ahead and state that the effect of decrease in cash dividends is severe than an increase in cash dividends-dividend decline cause a larger decline in returns (Waweru \& Otieno, 2016). Dividends announcements contain information contentcompanies listed in Nairobi Securities Exchange (NSE) should consider this before declaring any changes in cash dividend announcements (Waweru \& Otieno, 2016). Waweru and Otieno recommend a sector by sector research of the firms listed at NSE in order to test how share prices react to dividend change during different economic times. The authors did not conclude on the efficiency of the market.

\section{Excess Returns}

Olweny (2012) explored the extent to which dividend announcements have information content, its effect on firm value and the implication this has on the semi strong efficiency of the Nairobi Stock Exchange (NSE). The author used stock prices and dividend announcements data for the period 1999 to 2003 from the firms listed at NSE. The event study methodology was employed with and estimation period of 100 days, four firms were selected out of the 52 listed companies at NSE. The companies were selected based on consistency in final dividend announcements. Pure secondary data was obtained from NSE for both stock prices and dividend announcements. The author defined the event to be studied as dividend announcements, the market model was used because it removes return portion associated with the variation of the market return. The estimation period excludes the event period to avoid any overlap influencing the model parameters. The abnormal returns calculated during the event period were cumulated to obtain CAR. The data parameter tests which rely on the assumption that individual firm's abnormal returns are normally distributed were used to test for significance of the abnormal returns during the event period. Barclays Bank of Kenya (BBK), NIC Bank and Standard Chartered Bank (SCB) and East African Breweries Limited met the author's criteria above. In 2003 East African Breweries paid the highest dividends while NIC recorded the lowest Dividend announcement. In percentage terms, SCB registered the highest percentage change in dividend announcement in a single year $71.43 \%$ in 1999 BBK on the other hand registered the highest negative percentage change $(-46.67 \%)$ in 2003. (Olweny, 2012). The author noted that the financial sector paid dividends almost at the same time, February or March. The null hypothesis that dividend announcements have no information content was rejected with 95 percent confidence level. The null hypothesis that dividend announcements have no influence on firm value is also rejected at the same level of confidence (Olweny, 2012). The results of the study showed a significant relationship between dividend announcements and firm value (Olweny, 2012). Olweny, further concludes existence of abnormal returns persisted for some time after the event day and investors can take advantage of it hence the NSE is not semi strong form efficient. The author recommends further research to be conducted on a sector by sector basis so that a clear picture can be drawn on the relationship between dividend announcements and stock prices on a sector by sector basis.

(Alagidede, 2011) Provides evidence on return predictability in Africa's emerging equity markets. The ability of stock markets to fulfil their roles in the pricing and allocation of capital and, in diversifying investment risk depends on their efficiency (Alagidede, 2011). Alagidede further states that interest in the African stock markets has been revitalized due to the low correlation with the other global markets from developed countries. The author obtained and used daily closing index data from Datastream, indices from six African markets were used namely; CASE 30 (Egypt), NSE 20 (Kenya), TUNINDEX (Tunisia), MASI (Morocco), FTSE/JSE (South Africa) and NSE All Share Index (Nigeria). The stocks included in the indices were selected based on market size, trading volume and sector representation which represented over $90 \%$ of total market capitalization and domestic company listings in Africa. Egypt, Tunisia and Morocco represented North Africa. Nigeria represented west Africa, Kenya and South Africa represented East and Southern Africa respectively. An ordinary least squares (OLS) model was used to examine the Abnormal Returns (AR), the residuals were tested if they independently and identically distributed (iid). If evidence was obtained which was against iid, the author looked beyond the linear model since investor's attitudes towards risk and expected returns are non-linear (Campbell, Lo, \& MacKinlay, 1997). Alagidede argued that since non-linearity occurs in various forms there is no single dominant test, the author therefore considered five statistical tests to test the residual; test for $(\mathrm{G})$ ARCH, BDS test for randomness, Tsay's (1986) test for threshold effects and the Hinich and Patterson (1995) and Hinich (1995) bi-covariance test. From the data analyzed; Egypt had the highest mean return while Kenya had the lowest while highest kurtosis occurred in Kenya and Tunisia, Egypt and Nigeria had the lowest kurtosis. All the returns series were positively skewed apart from South Africa. The 
Jarque-Bera test rejected the normality assumption for all the countries under the study (Alagidede, 2011). Return predictability was evident in all the stock markets under study, evidence obtained was inconsistent with weak-form efficiency. This could be attributed to, buy and hold strategy by investors, limited instruments, low turnover and weak legislation. Risk return trade off was analyzed, the risk premium is significant and positive for Kenya and Tunisia at the 5\% level implying that investors are compensated for the risk premium absorbed. For the other countries the relationship between mean returns and variance or standard deviation is insignificant implying that investors consider other risks apart from market volatility (Alagidede, 2011). Alagidede tested the asymmetry in African stock returns by examining the asymmetry in volatility, a fall in the value of a firm's stock causes the debt-to-equity ratio to rise (Alagidede, 2011). The E-GARCH-M was used, the parameters were positive and significant for Kenya, Morocco, and Nigeria. The findings were significant and consistent with existence of leverage effect on these markets. The existence of long memory is inconsistent with weak-form market efficiency, the FIGARCH estimates indicated the presence of long-memory in all return series. After controlling the results for nonlinearity, conditional heteroscedasticity and time varying premier, the author concludes that returns are predictable both in the mean and variance. Long memory is a major feature of African markets. Alagidade goes further and states that, investors in Kenya and Tunisia may be compensated for the risk assumed, leverage effect and leptokurtosis are not unusual to developed countries, but also prevalent in African stock returns (Alagidede, 2011).

\section{METHODOLOGY}

\section{A. Research design}

Empirical study was employed where tests were carried out for successive daily price changes of stocks trading at the NSE to determine the efficiency of the market. The design was adopted as it allows collection of large amounts of data from the target population. This design was useful in studying the randomness of stock price returns to test whether they reflect all available public information. A regression technique based on the event study methodology was used to determine existence of abnormal returns, parametric tests were performed to test the significance of the abnormal returns. This was supported by other authors who have used the model; (Campbell, Lo, \& MacKinlay, 1997), (Olweny, 2012), (Waithaka, Ngugi, Aiyabei, Itunga, \& Kirago, 2012). (Dharmarathne, 2013), (Kiremu, Galo, Wagala, \& Mutegi, 2013), (Kabiru, Ochieng, \& Kinyua, 2015), (Anwar, Singh, \& Jain, 2015), (Onoh \& Nkama O., 2016), (Waweru \& Otieno, 2016).

\section{B. Target Population}

The population of the study were all the companies quoted at the Nairobi Securities exchange. To ensure a well-represented sample size, it was important to have the entire population of listed companies and zero down to the companies that have data available for stock prices and dividend announcements. Secondary data was obtained from Bloomberg Professional Services over the period January 2009 to December 2015.

\section{Sampling frame}

In order to have a well-represented sample the sample consisted of companies that have continuously constituted the NSE 20 share index and/or traded for a period of three years from Jan 2009 to Dec 2015. A sample of each sector was considered in order to ensure that every sector was represented in drawing up the conclusions of the study. Apart from the security being part of the NSE 20 share index, the security ought to have paid dividend and traded during the event window and period. This will not only avoid issues of thin trading but also ensure we have data to check for abnormal returns.

\section{Event Study Specifications}

Three kinds of event windows were considered $[-1 ;+1]$, with hypothetical event day being day $0,[-5 ;+5]$, and for every day from -5 to +5 separately. The aim of looking at the days from -5 to +5 , was to look at the bigger view where due to inefficient markets the reaction to an event could continue for several days. Below is an event study timeline to illustrate;

\begin{tabular}{ll|l|l|} 
Estimation Period & \multicolumn{3}{|l|}{ Event Window } \\
\hline 55 days & 5 days & 5 days \\
$\mathrm{T}_{0}=-60$ & $\mathrm{~T}_{1}=-5$ & $\tau=0$ & $\mathrm{~T}_{2}=+5$
\end{tabular}

Figure 1: Event study timeline by the Author

\section{E. Return Calculation}

The returns are calculated in a continuously compounded fashion by performing a logarithmic transformation.

$$
\mathbf{R}_{\mathbf{i \tau}}=\operatorname{In}\left(\frac{\mathbf{P}_{\mathbf{i \tau}}+\mathbf{D}_{\mathbf{i \tau}}}{\mathbf{P}_{\mathrm{i \tau}-1}}\right)
$$

Where; $R_{i \tau}$ is the return for the day $\tau$ for stock $i, P_{i \tau}$ is the split-adjusted stock prices for the current trades, $P_{i \tau-1}$ is the split-adjusted stock prices for the preceding trades and $D_{i \tau}$ is the dividend for the day $\tau$, if available.

\section{F. Normal Returns}

To estimate the parameters of the normal return, the below regression should be performed;

$$
\begin{aligned}
& R_{i \tau}=\alpha_{i}+\beta_{i} R_{m \tau}+\varepsilon_{i \tau} \\
& E\left(\varepsilon_{i \tau}\right)=0 \quad \operatorname{Var}\left(\varepsilon_{i \tau}\right)=\sigma_{\varepsilon_{i \tau}}^{2}
\end{aligned}
$$

Where; $R_{i \tau}$ are the day $\tau$ returns on the security $i, R_{m \tau}$ are the returns on the market portfolio in the estimation period, $\alpha_{\mathrm{i}}$ and $\beta i$ are the coefficients to be estimated and $\sigma_{\varepsilon_{i \tau}}^{2}$ are the variance of the residual $\varepsilon_{i \tau}$

\section{G. Abnormal Return Calculation}

The abnormal return is the actual return on a security during the event window minus an estimate of its normal return (expected return unconditional the event taking place) over a 
chosen period (Campbell, Lo, \& MacKinlay, 1997) The formulae is as stated below;

$$
A R_{i \tau}=R_{i \tau}-E\left\langle R_{i \tau} \mid X_{\tau}\right\rangle
$$

Where; $A R_{i \tau}$, are abnormal returns for the day $\tau$ in an event window, $R_{i \tau}$ are actual returns for the day $\tau$ in an event window, and $E\left\langle R_{i \tau} \mid X_{\tau}\right\rangle$ are expected normal returns for the day $\tau$ in an event window

\section{H. Estimation of the Market Model}

Under the general conditions; ordinary least squares (OLS) is a consistent estimation procedure of the market model parameters (Mackinlay, 1997). For the $i^{\text {th }}$ firm in the event time, the OLS estimator for the market model parameters for an estimation window of observation are;

$$
\begin{aligned}
\hat{\beta}_{i} & =\frac{\sum_{\tau=T_{0}+1}^{T_{1}}\left(R_{i \tau}-\widehat{\mu}_{i}\right)\left(R_{m \tau}-\widehat{\mu}_{m}\right)}{\sum_{\tau=T_{0}+1}^{T_{1}}\left(R_{m \tau}-\widehat{\mu}_{m}\right)^{2}} \\
\hat{\alpha}_{i} & =\hat{\mu}_{i}-\hat{\beta}_{i} \hat{\mu}_{m} \\
\hat{\sigma}_{\varepsilon_{i}}^{2} & =\frac{1}{L_{1}-2} \sum_{\tau=T_{0} \mp 1}^{T_{1}}\left(R_{i \tau}-\hat{\alpha}_{i}-\hat{\beta}_{i} R_{m \tau}\right)^{2}
\end{aligned}
$$

Where;

$$
\begin{aligned}
& \hat{\mu}_{i}=\frac{1}{L_{1}} \sum_{\tau=T_{0}+1}^{T_{1}} R_{i \tau} \\
& \hat{\mu}_{m}=\frac{1}{L_{1}} \sum_{\tau=T_{0}+1}^{T_{1}} R_{m \tau}
\end{aligned}
$$

Where; $R_{i \tau}$ is the return in event period $\tau$ for security $i, R_{m \tau}$ is the return in event period $\tau$ for market

\section{Existence of Abnormal Returns}

Given the market model parameters above, the abnormal returns can be derived;

$$
\widehat{A R}_{i \tau}=R_{i \tau}-\hat{\alpha}_{i}-\hat{\beta}_{i} R_{m \tau}
$$

Therefore, it is true to say;

$$
\widehat{A R}_{i \tau}=R_{i \tau}-E\left\langle R_{i \tau} \mid X_{\tau}\right\rangle=R_{i \tau}-\hat{\alpha}_{i}-\hat{\beta}_{i} R_{m \tau}
$$

The abnormal Return is the disturbance term of the market model calculated on out of sample basis. Under the null hypothesis, conditional on the event window returns, the abnormal returns should be jointly normally distributed with a zero conditional mean and conditional variance (Mackinlay, 1997).

Where;

$$
\sigma^{2}\left(\widehat{A R}_{i \tau}\right)=\sigma_{\varepsilon_{i}}^{2}+\frac{1}{L_{1}}\left[1+\frac{\left(R_{m \tau}-\widehat{\mu}_{m}\right)^{2}}{\widehat{\sigma}_{m}^{2}}\right]
$$

The below null hypothesis was tested;

$\mathrm{H}_{0}$; Dividends announcements have no impact on the behavior of stock prices (mean or variance). Under $\mathrm{H}_{0}$ the distributional of the sample abnormal returns of a given observation in the event window is;

$$
\widehat{A R}_{i \tau} \sim N\left(0, \sigma^{2}\left(\widehat{A R}_{i \tau}\right)\right)
$$

\section{J. Aggregation of abnormal returns to determine market reaction and price convergence;}

Where $\widehat{C A R}\left(\tau_{1}, \tau_{2}\right)$ is the sample cumulative abnormal return (CAR) from $\tau_{1}$ to $\tau_{2}$ where; $T_{1}<\tau_{1} \leq \tau_{2} \leq T_{2}$. The CAR from $\tau_{1}$ to $\tau_{2}$ is the sum of the included abnormal returns;

$$
\widehat{C A R}\left(\tau_{1}, \tau_{2}\right)=\sum_{\tau=\tau_{1}}^{\tau_{2}} \widehat{A R}_{i \tau}
$$

As $L_{1}$ increases the variance of $\widehat{C A R}_{i}$ is;

$$
\sigma_{i}^{2}\left(\tau_{1}, \tau_{2}\right)=\left(\tau_{2}-\tau_{1}+1\right) \sigma_{\varepsilon_{1}}^{2}
$$

The distribution of the cumulative abnormal return under $H_{0}$ is;

$$
\widehat{C A R}\left(\tau_{1}, \tau_{2}\right) \sim N\left(0, \sigma_{i}^{2}\left(\tau_{1}, \tau_{2}\right)\right)
$$

Given the null distributions of the abnormal return and the cumulative abnormal return, tests of the null hypothesis can be conducted. However, tests with one event observation are not likely to be useful so it is necessary to aggregate. (Mackinlay, 1997). It is assumed that there is no clustering i.e. there is no any overlap in the event windows of the included securities. The abnormal returns can be aggregated as follows;

$$
\overline{A R}_{\tau}=\frac{1}{N} \sum_{i=1}^{N} \widehat{A R}_{i \tau}
$$

And for the Large $L_{1}$ its variance is

$$
\operatorname{var}\left(\overline{A R}_{\tau}\right)=\frac{1}{N^{2}} \sum_{i=1}^{N} \sigma_{\varepsilon_{1}}^{2}
$$

Using the above estimates the abnormal returns for any event period can be analysed. The average abnormal returns were aggregated over the event window using the same approach as that used in calculating the cumulative abnormal returns for each security $i$ for any interval in the event window;

$$
\overline{C A R}\left(\tau_{1}, \tau_{2}\right)=\sum_{\tau=\tau_{1}}^{\tau_{2}} \overline{A R}_{\tau}
$$

One can therefore aggregate the $\overline{C A R}$ security per security and then divide by the number of securities (N) for the $\overline{C A R}$ of the sector or the market.

$$
\begin{aligned}
& \overline{C A R}\left(\tau_{1}, \tau_{2}\right)=\frac{1}{N} \sum_{i=1}^{N} \overline{C A R}\left(\tau_{1}, \tau_{2}\right) \\
& \operatorname{var}\left(\overline{C A R}\left(\tau_{1}, \tau_{2}\right)\right)=\sum_{\tau=\tau_{1}}^{\tau_{2}} \operatorname{var}\left(\overline{A R}_{\tau}\right)
\end{aligned}
$$

Inferences about these cumulative abnormal returns can be drawn using;

$$
\overline{C A R}\left(\tau_{1}, \tau_{2}\right) \sim N\left[0, \operatorname{var}\left(\overline{C A R}\left(\tau_{1}, \tau_{2}\right)\right)\right]
$$

\section{K. Diagnostic Tests for CAAR for information content of dividends}

Parametric Test - Ordinary Student t-distribution

To test the null hypothesis that the abnormal returns are zero. In practice because $\sigma_{\varepsilon_{1}}^{2}$ is unknown an estimator must be used to calculate the variance of the abnormal returns. The usual sample variance measure of $\sigma_{\varepsilon_{1}}^{2}$ from the market model regression in the estimation window is an appropriate choice (Mackinlay, 1997). Using this to calculate $\operatorname{var}\left(\overline{A R}_{\tau}\right)$ above $H_{0}$ can be tested using;

$$
t_{C A R}=\frac{\overline{C A R}\left(\tau_{1}, \tau_{2}\right)}{\operatorname{Var} \overline{C A R}\left(\tau_{1}, \tau_{2}\right)^{1 / 2}} \sim N(0,1)
$$

The cumulative abnormal returns are assumed to follow a student-t distribution. The calculated $t$-value would be compared with the critical value of the t-statistic at $\mathrm{N}-1$ degrees of freedom from the tables to determine the significance of the average cumulative abnormal returns. Parametric tests; which rely on the assumption that individual firm's abnormal returns are normally distributed and there is no clustering hence no cross- sectional correlation between the returns. 


\section{RESULTS AND DISCUSSIONS}

Table I below summarises the number of firms that met the sample criteria per sector and the number of dividend announcements used as the event.

Table I: Distribution Of Sample Dividends Used In The Study

\begin{tabular}{lcc}
\hline Sector & $\begin{array}{c}\text { No. Of } \\
\text { Firms }\end{array}$ & $\begin{array}{c}\text { Dividend } \\
\text { Announcements }\end{array}$ \\
\hline Agricultural & 3 & 23 \\
Banking & 4 & 29 \\
Commercial \& Services & 2 & 11 \\
Construction \& Allied & 3 & 30 \\
Energy \& Petroleum & 3 & 19 \\
Insurance & 3 & 23 \\
Man. \& Allied & 3 & 37 \\
Tel. \& Technology & 1 & 7 \\
\hline TOTAL & $\mathbf{2 2}$ & $\mathbf{1 7 9}$ \\
\hline
\end{tabular}

\section{A. Descriptive Statistics}

The Agriculture sector had the highest Mean Average Abnormal Returns at $0.64 \%$ an indication that on average the Agriculture Sector provided the highest returns at the NSE market compared to all the other sectors. The Commercial and Services Sector was second at $0.4 \%$ followed by the Manufacturing at $0.33 \%$. Insurance at $0.07 \%$ and Energy at $0.19 \%$ provided the least mean returns at the NSE compared to the other sectors. Most of the sectors had AAR positively skewed apart from The Commercial and Services sector which was -1.6. Compared to the rest the Energy and petroleum sector had the highest Skewness at +3.03 indicating that Abnormal Returns were evident before the event date $(\tau=0)$. The Energy and petroleum sector had the highest Kurtosis at 9.6 while the Manufacturing \& Allied sector had the lowest Kurtosis at 1.5 excess of normal data Kurtosis at three.

Table II: Descriptive Statistics per Sector \& the Market for Average Abnormal Returns

\begin{tabular}{|c|c|c|c|c|c|}
\hline Sector & CAAR & Median & Mean & Skewness & Kurtosis \\
\hline Agric. & $7.1 \%$ & $0.5 \%$ & $0.6 \%$ & 1.90 & 4.31 \\
\hline Banking & $3.2 \%$ & $-0.1 \%$ & $0.3 \%$ & 2.90 & 8.91 \\
\hline $\begin{array}{l}\text { Com. \& } \\
\text { Services }\end{array}$ & $4.4 \%$ & $0.5 \%$ & $0.4 \%$ & -1.61 & 3.29 \\
\hline Const. & $3.1 \%$ & $-0.1 \%$ & $0.3 \%$ & 2.38 & 6.46 \\
\hline Energy & $2.1 \%$ & $-0.2 \%$ & $0.2 \%$ & 3.03 & 9.61 \\
\hline Insurance & $0.8 \%$ & $-0.1 \%$ & $0.1 \%$ & 2.16 & 6.35 \\
\hline Manu & $3.6 \%$ & $0.2 \%$ & $0.3 \%$ & 1.36 & 1.51 \\
\hline $\begin{array}{l}\text { Tel. \& } \\
\text { Tech. }\end{array}$ & $2.4 \%$ & $-0.1 \%$ & $0.2 \%$ & 1.87 & 5.22 \\
\hline $\begin{array}{c}\text { NSE } \\
\text { Market }\end{array}$ & $26.6 \%$ & $0.02 \%$ & $2.4 \%$ & 3.03 & 9.57 \\
\hline
\end{tabular}

Figure 2 below indicates an increasing trend of activities an indicator of more trading happening at the market. A drop of activities in the market around 2008-2009 is evident which can be attributed to both the post-election violence in Kenya and the global financial crisis. The same drop is seen in 20122013 when elections were held in Kenya (Menge, Mwangi, \& Kimani, 2014), (Kabiru, Ochieng, \& Kinyua, 2015)

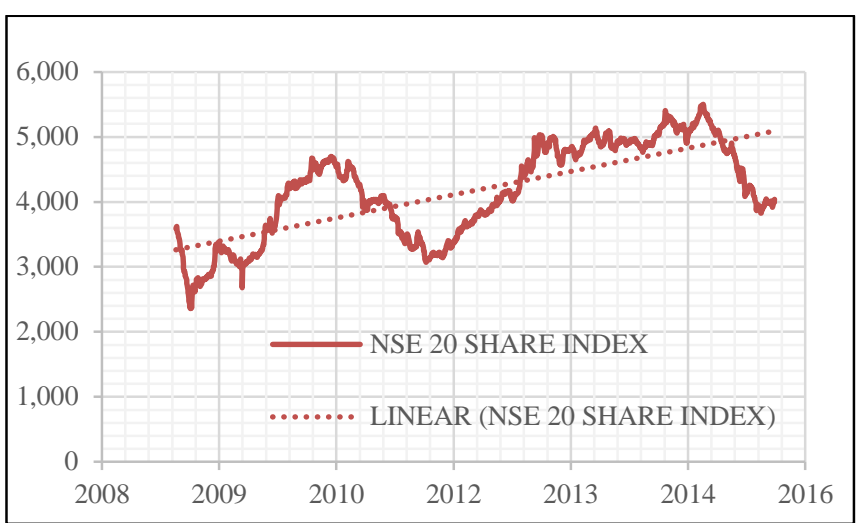

Figure 2: Graph of NSE 20 Share index from 2009 to 2016

\section{B. Information content of dividend announcements to market prices}

Table III below indicates the t-statistics (equation 3.23) for the Cumulative Abnormal Returns carried out for all the sectors in the study and the market during the event window. The Variance of CAAR (equation 3.21) was also calculated and the Standard deviation being the square root of the variance.

Table III: Variance and Parametric Test per Sector \& the Market

\begin{tabular}{|c|c|c|c|c|}
\hline Sector & Var & S. Dev & $\begin{array}{c}\text { Test } \\
\left(t_{C A R}\right)\end{array}$ & $\begin{array}{c}\text { Sig. } \\
\text { @ 96\% } \\
\text { Cl }\end{array}$ \\
\hline Agric & 0.000955 & 0.030900 & 2.293932 & Yes \\
\hline Banking & 0.000095 & 0.009744 & 3.294769 & Yes \\
\hline $\begin{array}{l}\text { Com. } \\
\text { Ser. }\end{array}$ & 0.000193 & 0.013901 & 3.196462 & Yes \\
\hline $\begin{array}{l}\text { Con. } \\
\text { Allied }\end{array}$ & 0.000101 & 0.010060 & 3.034096 & Yes \\
\hline Energy & 0.000147 & 0.012104 & 1.696862 & No \\
\hline Insurance & 0.000240 & 0.015500 & 0.504914 & No \\
\hline $\begin{array}{l}\text { Man \& } \\
\text { Al. }\end{array}$ & 0.000088 & 0.009383 & 3.867003 & Yes \\
\hline Telecom. & 0.000030 & 0.005456 & 4.369368 & Yes \\
\hline $\begin{array}{l}\text { NSE } \\
\text { Market }\end{array}$ & 0.001849 & 0.042997 & 0.781535 & No \\
\hline \multicolumn{5}{|c|}{$\begin{array}{l}\text { For the five sectors namely; Agricultural, Banking, } \\
\text { Commercial, Construction, Manufacturing and Telecomm } \\
\text { Sectors. Evidence from the research indicate that the null } \\
\text { hypothesis: Dividends announcements have no impact on the } \\
\text { behavior of stock prices is rejected at } 96 \% \text { Confidence level. } \\
\text { These reaction of the market to dividends announcements } \\
\text { agrees with the Efficient Market Hypothesis (EMH) theory }\end{array}$} \\
\hline
\end{tabular}


which suggest that dividends announcements do possess information content. The empirical findings are consistent with (Arnott \& Asness, 2001), (Hasan, Akhter, \& Huda, 2012), (Waithaka, Ngugi, Aiyabei, Itunga, \& Kirago, 2012), (Dharmarathne, 2013), (Bulla, 2016). However, for the Energy Sector, Insurance Sector and the NSE Market, the null Hypothesis, is accepted at 96\% Confidence level, concluding that Dividend announcements have no impact on the behavior of stock prices for the two sectors and the market.

\section{Price Convergence to new values}

To test how quickly prices, converge to the new theoretically correct fundamental values after an announcement and whether the market reacts efficiently; we need to evaluate the stock prices movements during the event window; i.e. before and after the date of dividend announcements (refer to Fig. 3 below). During the event window we expect prices to react instantaneously to their true fundamental price after the announcement. Generally, from the data obtained post the event date the CAAR is not stable; an indication that it takes more than five days after the event for market prices to converge to the new theoretically correct fundamental values. The high volatility creates room for market players to beat the market. The empirical findings are consistent with (Mlonzi, Kruger, \& Nthoesane, 2011), (Anwar, Singh, \& Jain, 2015), (Onoh \& Nkama O., 2016).

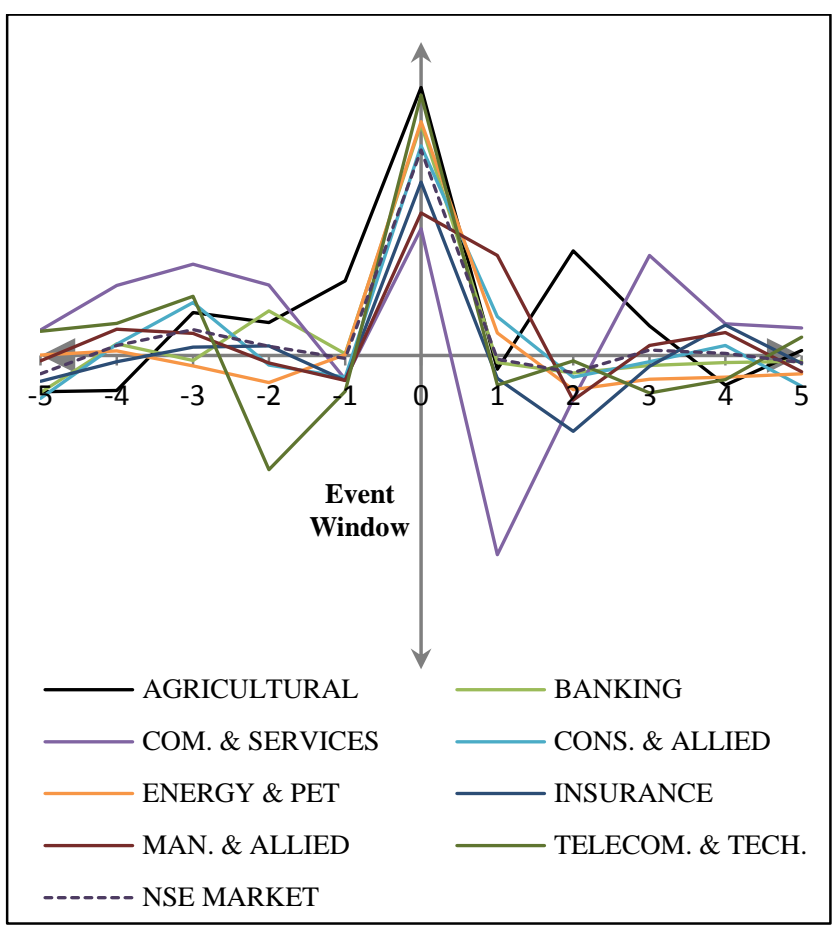

Figure 3: Graph of Abnormal Returns during the event window per sector $\&$ the market

\section{Market reaction to announced information}

From fig 4 we can see some prices reacting before the event date an indication there is leak of information (insider trading). In addition, it's evident that market prices take longer to adjust to the true prices after announcement.

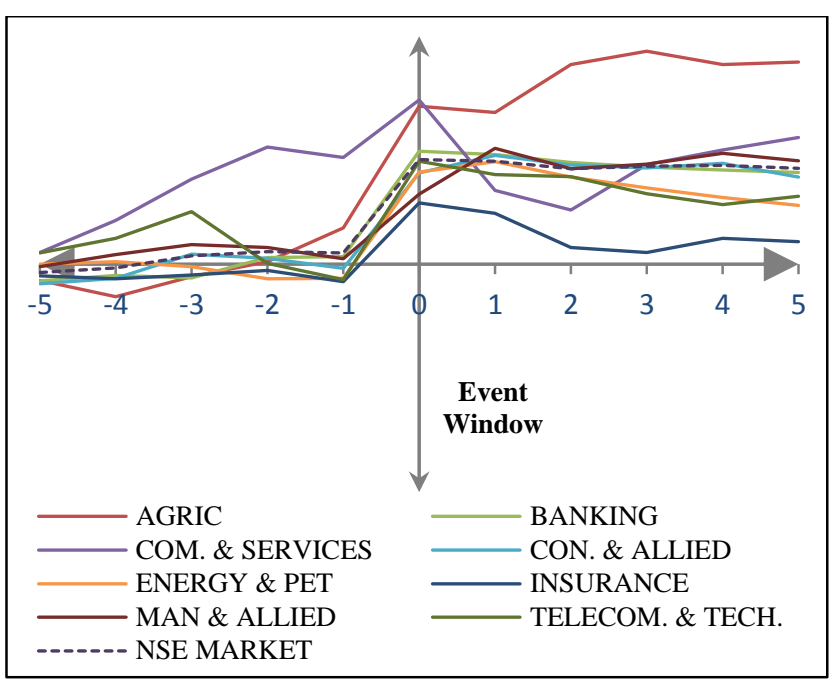

Figure 4: Graph of Cumulative Average Abnormal Returns (CAAR) during the event window per sector and the market

\section{E. Abnormal Returns during the Event Window}

If abnormal returns exist during the event window; market players can take advantage and beat the market buy either selling or buying securities. The descriptive statistics shown in Table II depict presence of abnormal returns across all sectors, with the Agriculture sector having the highest CAAR and the highest variance.

\section{F. Summary of hypothesis testing}

From the findings of the research dividend announcements do have an impact on the behaviour of stock prices for the Agricultural, Banking, Commercial, Construction, Manufacturing and Telecomm Sectors. However, for the Energy Sector, Insurance Sector and the NSE Market in general, dividend announcements have no impact on the behaviour of stock prices. In addition, there is empirical evidence of price movements before dividend announcements; an indication of information asymmetry. After dividend announcements there is a sluggish response of stock prices where it takes more than five days for prices to adjust to their correct values. This makes it possible for market players to profit from this inefficiency by either selling or buying stocks and earning abnormal returns hence the Nairobi Securities Exchange has not attained the semistrong form of market efficiency.

\section{CONCLUSION}

From the findings of the study dividend announcements do have an impact on the behaviour of stock prices for the Agricultural, Banking, Commercial, Construction, Manufacturing and Telecomm Sectors. On the other hand, for the Energy Sector, Insurance Sector and the NSE Market in general, dividend announcements have no impact on the behaviour of stock prices. In addition, there is empirical evidence of price movements before dividend announcements; an indication of information asymmetry. Subsequently, after dividend announcements there is a sluggish response of stock prices where it takes more than five days for prices to adjust to their correct values. This 
makes it possible for market players to profit from this inefficiency by either selling or buying stocks and earning abnormal returns. Due to the above compelling evidence we confidently conclude that the Nairobi Securities Exchange is not semi-strong form efficient.

Existence of Abnormal Returns before the event date draws questions on whether some information which is not available to the wider public may have licked. It is therefore interesting if a research can be conducted to test the possibility of insider trading at the NSE market. At the same time the speed at which stock adjust to information is of concern especially when no arbitrage profits are to be realized; we have evidenced a lot of changes on the market structure and a future research agenda would provide more insights to whether the changes have an impact on the speed of price formation.

\section{REFERENCES}

1. Alagidede, P. (2011, May). Return behaviour in Africa's emerging equity markets. The Quarterly Review of Economics and Finance, 51(2), 133-140. Retrieved from https://doi.org/10.1016/j.qref.2011.01.004

2. Anwar, S., Singh, S., \& Jain, P. K. (2015). Cash Dividend Announcements and Stock Return Volatility: Evidence from India. Procedia Economics and Finance Journal, 38-49.

3. Arnott, R. D., \& Asness, C. S. (2001, December). Does Dividend Policy Foretell Earnings Growth? Retrieved 2017, from SSRN's e-library: https://papers.ssrn.com/sol3/papers.cfm?abstract_id $=295974$

4. Balachandran, B., Dempsey, M., \& Mahamuni, M. (2009, October). Special Dividend Announcements: Signaling or Free Cash Flow Hypothesis? Evidence from UK Firms. SSRN Electronic Journal.

5. Betzer, A., \& Theissen, E. (2007, March). Insider Trading and Corporate Governance - The Case of Germany. Retrieved from https://www.econstor.eu/handle/10419/57720

6. Brown, S., \& Warner, J. (1980). Measuring security price performance. Journal of Financial Economics (8), 205-258.

7. Brown, S., \& Warner, J. (1985). Using Daily Stock Returns: The Case of Event Studies. Journal of Financial Economics (14), 3-31.

8. Bulla, D. M. (2016). Dynamics of Dividend Payout in Emerging Stock Markets: Evidence from Listed Firms at Nairobi Securities Exchange, Kenya. Jomo Kenyatta University of Agriculture and Technology (JKUAT), Department of Entrepreneurship and Procurement. ResearchGAte.

9. Campbell, J. Y., Lo, A. W., \& MacKinlay, A. C. (1997). The Econometrics of Financial Markets. In The Econometrics of Financial Markets (pp. 141-
181). Princeton, New Jersey: Princeton University Press.

10. Campbell, J., Lo, A., \& MacKinlay, A. (1997). The Econometrics of financial markets. Princeton, US: Princeton University Press.

11. Cao, J., Chordia, T., \& Lin, C. (2016, October). Alliances and Return Predictability. Journal of Financial and Quantitative Analysis, 51(5), 16891717. Retrieved from http://ssrn.com/abstract=2409609

12. Capital Markets Master Plan Steering Committee (CMMSC). (2014). Capital Markets Master Plan 2014-2023. Nairobi: Capital Markets Authority of Kenya.

13. Chen, Y., \& Oriani, R. (2015). Cross-listings, signalling and free cash flow: An examination of the Hong Kong and the Chinese stock markets' reaction to dividend announcements. LUISS Guido Carli University.

14. CMA. (2014, October 27). Retrieved October 27, 2014, from Capital Markets Authority Kenya: http://www.cma.or.ke/index.php?option=com_doc man\&view $=$ docman $\&$ Itemid $=396$

15. Dharmarathne, D. G. (2013, October). Stock price reaction to dividend announcements and information efficiency in Sri Lankan share market. International Journal of Research In Social Sciences, 3(2).

16. Fama, E. (1991). Efficient capital markets: II. The Journal of Finance, 46(5), 1575-1617.

17. Fama, E. F. (1965-1974). Random Walks in Stock Market Prices.

18. Fama, E. F. (1970). Efficient Capital Markets: A review of theory and and empirical work. Journal of Finance.

19. Fama, E. F. (1991). Efficient Capital Markets: II. The Journal of Finance, XLVI(5), 1575-1617.

20. Fuller, K., \& Thakor, A. (2010, January). Signaling, Free Cash Flow, And "Nonmonotonic" Dividends. The Financial Review, 45, 21-56.

21. Griffin, J., Kelly, P., \& Nardari, F. (2009, June 23). Are Emerging Markets More Profitable? Implications for Comparing Weak and Semi-Strong Form Efficiency. Retrieved from https://papers.ssrn.com/sol3/papers.cfm?abstract_id $=959006$

22. Hasan, S. B., Akhter, S., \& Huda, H. A. (2012). Cash Dividend Announcement Effect: Evidence from Dhaka Stock Exchange. Research Journal of Finance and Accounting, 3(2), ISSN 2222-1697 (Paper) ISSN 2222-2847 (Online). Retrieved from www.iiste.org

23. Jansen, M. (1968). The performance of Mutual funds in the period 1945-1964. The Journal of finance, 23(2), 389-416. 
24. Johannes, P. S. (2015). Testing the Strong-Form Efficiency of the Namibian Stock Market. International Review of Research in Emerging Markets and the Global Economy (IRREM), 1(4).

25. John, K., \& Williams, J. (1985, September). Dividends, Dilution, and Taxes: A Signalling Equilibrium. The Journal of Finance, 40(4), 10531070.

26. Kabiru, J. N., Ochieng, D. E., \& Kinyua, H. W. (2015, October). The Effect of General Elections on Stock Returns at the Nairobi Securities Exchange. European Scientific Journal, 11(28), 1857-7881.

27. Kiremu, M. K., Galo, N., Wagala, A., \& Mutegi, J. K. (2013, February). Stock Price and Volumes Reaction to Annual Earnings Announcement: A Case of the Nairobi Securities Exchange. International Journal of Business, Humanities and Technology, 3(2). Retrieved from www.ijbhtnet.com

28. Kolari, J. W., \& Pynnonen, S. (2010). Nonparametric Rank Tests for Event Studies. Journal of Empirical Finance.

29. Mackinlay, C. (1997, March). Event Studies in Economics and Finance. Journal of Economic Literature, XXXV, 13-39.

30. Malhotra, M., Thenmozhi, M., \& Kumar, G. A. (2007). Stock Market Reaction and Liquidity Changes around Bonus Issue: Evidence from India. 10th Capital Markets Conference, Indian Institute of Capital Markets Paper. Retrieved from https://ssrn.com/abstract=962830

31. Menge, R. N., Mwangi, M., \& Kimani, J. G. (2014, June 7). Effect of elections on stock market returns at the Nairobi securities exchange. Prime Journal of Social Science, 3(6), 763-768.

32. Mlonzi, V., Kruger, J., \& Nthoesane, M. (2011). Share price reaction to earnings announcement on the Johannesburg Stock Exchange -JSE ALtX-A test for Market efficiency. Southern African Business Review, 15(3).

33. Muragu, K. (1990). Stock market efficiency in developing countries: a case study of the Nairobi Stock Exchange. 52-70.
34. Muthama, N. (2013). An empirical investigation of the random walk hypothesis of stock prices on the Nairobi Stock Exchange. European Journal of Accounting Auditing and Finance Research, 33-59.

35. Nairobi Securities Exchange (NSE). (2015, October 08). Retrieved October 2015, from Nairobi Securities Exchange Limited:

https://www.nse.co.ke/nse/history-of organisation.html

36. Olweny, T. (2012). Dividend Announcement and Firm Value: A Test of Semi Strong Form of Efficiency at the Nairobi Stock Exchange. Asian Social Science, 161-175.

37. Onoh, J. O., \& Nkama O., N. (2016). Semi-Strong Market Efficiency Studies of the Nigerian Capital Market Using Dividend Announcements. Journal of Business and African Economy, 2(1). Retrieved from www.iiardpub.org

38. Oxford Business Group. (2016). Capital Markets Chapter on Kenya.

39. Ross, S. A. (1977). The Determination of Financial Structure: The Incentive-Signalling Approach. The Bell Journal of Economics, 8(1), 23-40.

40. Thirikwa, G. M., \& Olweny, T. (2015, August). Determinants Of Herding In The Nairobi Securities Exchange. Economics and Finance Review, 4(05), 14-30. Retrieved from http://www.businessjournalz.org/efr

41. Waithaka, S. M., Ngugi, J. K., Aiyabei, J. K., Itunga, J. K., \& Kirago, P. (2012, August 23). Effects of dividend policy on share prices: A case of companies in Nairobi Securities Exchange. Prime Journal of Business Administration and Management (BAM) (ISSN: 2251-1261), 642-648,. Retrieved from www.primejournal.org/BAM

42. Waweru, F. M., \& Otieno, P. A. (2016). Cash Dividend Change Announcement Effect on Share Price Returns: Evidence from Nairobi Securities Exchange. The International Journal of Business and Finance Research, 10(3), 39-47. 